\title{
Grey Markets in Customer-to-Customer Transaction and Social Networking - The Case of Vietnam
}

\author{
Bình Nghiêm-Phú
}

\begin{abstract}
Manuscript type: Research paper

Research aims: This study aims to examine the Facebook-based grey market transactions of female customers in Vietnam. Specifically, this study investigates why (the reasons) and how (the ways) Vietnamese customers purchase grey (unofficial parallel imported) products on Facebook.

Design/Methodology/Approach: Semi-structured interviews were conducted with thirteen female customers who had purchased grey products bought in Japan. Content analysis was applied and findings were discussed.

Research findings: The Vietnamese unofficial parallel imported products (UPIP) or grey market has transformed itself into an online customer-to-customer (C2C) market with all the characteristics of an e-commerce market, thanks to the development of social media platforms such as Facebook. This market is expanding because it can fulfil the diverse needs of Vietnamese consumers whose incomes are expanding but whose needs are not satisfied. Buyers enter the market after carefully consulting their own experiences and those of their acquaintances. However, due to their lack of experience in
\end{abstract}

\footnotetext{
Nghiêm-Phú Bình is currently an Assistant Professor at the Department of Business Communication, National of Institute Technology - Fukushima College, 30 Taira Kamiarakawa Nagao, Iwaki, Fukushima 970-8034 Japan. Email address: binhnghiem@fukushima-nct.ac.jp and binhnghiem@gmail.com

Acknowledgement: The author would like to sincerely thank Dr. Hồng Long Phạm, Mr. Thế Ninh Nguyễn (PhD Candidate), Ms. Thu Hương Kiều (PhD Candidate), and Ms. Quỳnh-Anh Lê (MBA) for their invaluable help and support. This paper cannot be composed without their contributions.
}

https://doi.org/10.22452/ajba.vol11no2.9 
buying and using the products in the country of origin, consumers may over-trust the sellers and be taken advantage of.

Theoretical contribution/Originality: The grey market of Vietnam has partly merged with the $\mathrm{C} 2 \mathrm{C}$ market and the e-commerce market. Grey market customers are better supported by the development of social networking sites (e.g., Facebook) which serve as powerful tools for customer reviews. The grey market, therefore, has been turned into an open one. However, due to the lack of a strong and effective legal framework, it is still unofficial. In addition, since social media platforms have already been transformed into real shopping venues, customers can presently enjoy a personalised service with many of their niche needs met satisfactorily.

Practitioner/Policy implications: Legal brand owners should consider opening official stores in Vietnam to exploit the promise of a market whose spending power is the best in the Southeast Asian region. However, before any official entry initiatives are undertaken, a careful market research and a trial basis is necessary. In addition, the Vietnamese government should implement a non-tax policy for social-media-based grey traders as a measure to control the import of illegal or harmful products. The government should also facilitate the introduction of an e-commerce law.

Research limitations: This study only captured the opinions of female customers from one urban area of buying UPIPs on Facebook. Those of the male and rural consumers were not investigated. In addition, the current study focused on the buyers' side of the UPIP transaction and had excluded the sellers' perspective. Moreover, this study only focused on Vietnam. The activities of the Facebook-based UPIP markets in other countries were overlooked.

Keywords: C2C, Facebook, Grey Market, Social Media, Vietnam JEL Classification: M00

\section{Introduction}

A grey market (i.e., a parallel or diverted imports/goods market) is a market of genuine trademarked products sold by unauthorised distributors (Antia, Bergen, Dutta, \& Fisher, 2006). Born as a secretive entity (Malueg \& Schwartz, 1994), grey markets have now been legalised in many countries and territories such as America, Australia, China, Japan, New Zealand, Singapore, Taiwan and the European Union (Gallini \& Hollis, 1999; Hwang, Peng, \& Shih, 2014). The grey market has also manifested itself on the online environment. In Vietnam, at least 300,000 people are estimated to be selling products on Facebook (Tomiyama, 
2016). Many of these products (i.e., "hàng xách tay" in Vietnamese) are said to be those (legally) bought from abroad (e.g., America, Australia, France, Japan, Korea and Thailand), carried to Vietnam through the means of air passenger luggage and then sold to domestic Vietnamese users (without agreements from the legal producers and/or distributors and without the official control of Vietnamese customs and market management organisations). These products are, undoubtedly, grey products and the Facebook-based market is indeed a grey market.

However, investigations of the grey market issues have mainly focused on the activities of grey importers and legal stakeholders, and the interactions between them (Altug \& Sahin, 2018; Simba, Smith, \& Dube, 2018). Research on customer-related issues is less significant (Huang, Lee, \& Ho, 2004; Liu, Chang, \& Lin, 2012). In addition, previous studies had not accounted for the significant development of technology (e.g., mobile devices and social media networks) and the growing power that present day customers have due to such technological developments (Kim \& Johnson, 2016; Lamberton \& Stephen, 2016). Although there is research, few have relatively attempted to look at the grey market in Vietnam (Kuanpoth, 2007). Consequently, existing literature have overlooked the new development of the market as well as other potential participants in the market.

A grey market generally emerges from two perspectives (Richardson, 2002). From the supplier's perspective, there are benefits for grey importers since they do not have to invest in building a reputation and providing extra services (Knoll, 1961). From the customer's perspective, there are demands for cheaper products which are imported without an authorised agreement (Malueg \& Schwartz, 1994). However, where there is no demand then there is no need for suppliers. This is especially true with products in the pre-entry and/or exit stages of their lifecycles (Klepper, 1996). Therefore, understanding customers' reasons for buying (why) and their ways of buying (how) is the very first step towards getting a better insight into the market.

The popularity of the grey market in Vietnam began in the 1980s when Vietnamese living in the Soviet republics sent home foreign goods to be resold. The grey market can be considered a special form of customer-to-customer (C2C) transaction which is "the active or passive interaction between two or more customers inside or outside the service setting" (Johnson \& Grier, 2013, p. 306). Different from the business-tobusiness (B2B), business-to-customer (B2C) and customer-to-business (C2B) models, the $\mathrm{C} 2 \mathrm{C}$ facilitates the transaction of products and/or 
services between customers (Hom, 2013). Some famous C2C platforms include auction sites such as eBay and Taobao (Li, Li, \& Lin, 2008) and multipurpose portals such as Craigslist and Facebook (Santus, 2015). Nonetheless, unlike the C2C transactions in other countries, Facebookbased $\mathrm{C} 2 \mathrm{C}$ buying and selling activities in Vietnam are not (or cannot be) controlled strictly by the government (e.g., an e-commerce law has not been passed yet). Vietnamese Facebook merchandisers do not have to report their activities and their incomes; they are also not required to pay taxes to the government, until very recently (2018). In addition, buyers are frequently cheated and unprotected. Thus, if not controlled, foreign retailers and brand owners who are and will be entering the Vietnamese retail market may be affected by the current grey market activities. Unfortunately, this aspect of research focusing on grey markets has not been explored by existing literature.

Grounded on these understandings, the current study aims to examine the Facebook-based grey market in Vietnam with a focus on customer behaviour. Specifically, this study investigates why Vietnamese users buy grey products and how they buy these products on Facebook.

This study will contribute to the literature on grey market by providing a new context (Vietnam), a new location (online) and a new era (the late 2010s) of findings. In addition, this study provides government agencies with practical implications for the management of the market, especially the creation of a legal framework and the operation of managerial activities. It also adds more recent insights into the control of entry activities of legal providers in the near future. The remainder of this paper is organised into seven sections. Section 2 reviews the relevant literature. Section 3 describes the data and methodology while section 4 reports the results. Section 5 and section 6 discusses the results and implications of the findings. Finally, section 7 concludes the paper.

\section{Theoretical Framework}

\subsection{Social Media Usage}

Social media "is a group of Internet-based applications that build on the ideological and technological foundations of web 2.0 which allow the creation and exchange of user generated content" (Kaplan \& Haenlein, 2010, p. 61). Social media helps to facilitate the development of online social networks through social networking activities. Thus social media 
is also regarded as a social networking platform, for example, Facebook, Flickr, Instagram, Pinterest, Twitter and YouTube.

In recent years, research on social media (e.g., business marketing, public relations, communication and behaviours) has been increasing (Khang, Ki, \& Ye, 2012; Ngai, Tao, \& Moon, 2015). In the marketing sector, for instance, research has attempted to understand the effects of induced and organic marketing efforts (advertisement and wordof-mouth), brand management, customer relationship management, and customer perception and behaviour, among others (Alalwan, Rana, Dwivedi, \& Algharabat, 2017). In practice, businesses have adopted social media into their electronic commerce activities and created what has been termed as social commerce channels since the late 2000s (Turban, King, Lee, Liang, \& Turban, 2015). Companies run their own Facebook or Twitter pages to interact with their customers (Dijkmans, Kerkhof, \& Beukeboom, 2015; Michaelidou, Siamagka, \& Christodoulides, 2011). This allows customers to participate actively in the discussion and purchase of products and services on the networking sites of their favourite brands (Cox \& Park, 2014; Zhang, Omran, \& Cobanoglu, 2017). Some influential customers also run their own pages and/or channels on social networking sites to provide their audience with a regular review of certain products and services (Hoyle, 2017). Consequently, customer-generated media has become an important source of reference for potential users (Ayeh, 2015).

Customers' use of the social media is affected by many factors. In their study, Kwon and Wen (2010) found that perceived ease of use, usefulness and encouragement are significant antecedents of the actual use of social networking sites in Korea. Focusing on Taiwan, Lin and $\mathrm{Lu}$ (2011) noted that perceived enjoyment is a significant predictor of future use intention. When looking at users' motivation in using social media, Young, Len-Ríos and Young (2017) observed that there were five dimensions: romantic, social belongingness, surveillance, information and entertainment. Similarly, Kim, Sohn and Choi's (2011) analysis found that users were motivated by five factors: seeking friends, seeking convenience, seeking social support, seeking information and seeking entertainment. This shows that motivation to use social media is diverse.

Social media may offer many benefits to its users, for example, social capital enhancement, new environment adaptation, life satisfaction, social trust and civic participation (DeAndrea, Ellison, LaRose, Steinfield, \& Fiore, 2012; Ellison, Steinfield, \& Lampe, 2007; Valenzuela, 
Park, \& Kee, 2009). Despite this, social networking sites may also contain several threats. One of the most serious concerns about social networking is privacy (e.g., the information about an individual and his/her acquaintances may be collected and used for grey and/or dark purposes) (Ellison, Vitak, Steinfield, Grey, \& Lampe, 2011). Other concerns include addiction, being affected by others, being asocial, cyberbullying and online harassment, depression, distraction, obligation, and a waste of time, among others (O'Keeffe \& Clarke-Pearson, 2011; Vural, 2015).

In line with its worldwide development, social media has been adopted by Vietnamese users since the late 2000s. It is estimated that approximately 38 and 44 million Vietnamese citizens are owners of social networking accounts in 2018 and 2020, respectively (Statista, 2018). These figures make up approximately 69 per cent and 73 per cent of the total Internet users in the country. However, research on Internetrelated issues in Vietnam has mainly focused on the good and bad of adopting Internet into their social lives and business activities (Lin, $\mathrm{Wu}$, \& Tran, 2015; Zhang, M.W.-B. et al., 2017). Studies focusing on the use of social media, unfortunately, are scare. In a rare attempt, Nguyen, Nguyen and Phung (2016) examined users' perception of the usefulness of Facebook-based information. Based on their findings, the researchers recommended that businesses use Facebook as an additional channel to communicate with their customers. Other than this, research looking at other aspects of the use of social media in the context of Vietnam, has largely, been overlooked.

\subsection{C2C Business on Social Media}

The $\mathrm{C} 2 \mathrm{C}$ business on social media is one dimension of electronic commerce. It refers to the electronic transaction occurring between or amongst individuals on social networking platforms (Turban et al., 2015). The most prevalent example of a social-media-based (SMB) C2C electronic commerce is online auctions such as eBay.

Researchers such as Stern, Royne, Stafford and Bienstock (2008) have studied the mechanism of consumer attitude toward online auction sites. They applied a model of technology acceptance to examine consumer intention. Their analysis revealed that respondents' intention toward online auction sites was affected by their perceived usefulness, perceived ease of use and also the impulsiveness of the shoppers' activities. Yeh, Hsiao and Yang (2012) added that another factor that could 
influence consumer intention was perceived uncertainty. Additionally, Yen and $\mathrm{Lu}$ (2008) found that satisfaction with both auctioneers and sellers was the antecedent of customers' repurchase intention.

Other researchers examined online auction activities from the suppliers' perspective. Becherer and Halstead (2004), for example, found that eBay sellers may choose between the two orientations of differentiation and cost leadership to guide their activities. However, orientations may change and auction platforms may also be switched. In the context of Taiwan, Lin, Cheng, Wang and Chang (2012) found that sellers' switching intention was affected by many important factors such as switching costs, fees and website qualities.

Electronic commerce $\mathrm{C} 2 \mathrm{C}$ in general and SMB C2C in particular helps to reduce administrative and commission costs for both the sellers and buyers (Turban et al., 2015). It also helps to eliminate the geographical limitations of traditional transactions and allows the flexibility of all transactions (Ariely \& Simonson, 2003). However, like any other electronic activities, the $\mathrm{SMB} \mathrm{C} 2 \mathrm{C}$ may pose several risk concerns, for example, privacy, fraud, inconveniences of assessment and shipment, and product quality, among others (Esper, Jensen, Turnipseed, \& Burton, 2003; Forsythe \& Shi, 2003; Miyazaki \& Fernandez, 2001; $\mathrm{Wu}, \mathrm{Li}, \& \mathrm{Kuo}, 2011)$. To overcome such issues and to reach a purchase decision, buyers rely on ratings and/or reviews or comments on sellers and their products (Amblee \& Bui, 2012; Phang, Zhang, \& Sutanto, 2013). In this sense, trust is an important element of any electronic transaction (Kim \& Peterson, 2017). Sellers, on the other hand, try to create and provide an interactive and reliable shopping environment as a means to attract and persuade customers to buy their products (Carter, Tams, \& Grover, 2017; de Vries, Gensler, \& Leeflang, 2012; Shen \& Bissell, 2013). This bidirectional or two-way feedback mechanism offered by the social networking platform (i.e., sellers and buyers review and rate each other) facilitates and guarantees such SMB C2C transactions (Weinberg $\&$ Davis, 2005). To offset risks and to make financial transactions more convenient, online escrow services (e.g., PayPal) are adopted by both the sellers and buyers (Antony, Lin, \& Xu, 2006).

In the context of Vietnam, some research (Tran, Zhang, Sun, \& Huang, 2014; Han, Nguyen, \& Nguyen, 2016) had been conducted to investigate issues related to electronic commerce and mobile commerce. Nonetheless, studies focusing on $\mathrm{C} 2 \mathrm{C}$ in general and $\mathrm{SMB} \mathrm{C} 2 \mathrm{C}$ in particular are still lacking. Existing studies (Che, Cheung, \& Thadani, 2017; Chen, Su, \& Widjaja, 2016) have mainly focused on the potential 
of social media as a shopping venue while actual $\mathrm{C} 2 \mathrm{C}$ transactions have been neglected.

\subsection{Parallel Market in Asian Countries}

Products and goods are materials manufactured for consumption. In cases where domestic markets are unable to manufacture such goods or where it is cheaper to buy them from other countries, imports are transacted (The Levin Institute, 2015). With developing countries, imported products, especially those from developed countries, have special appeals (Batra, Ramaswamy, Alden, Steenkamp, \& Ramachander, 2000; Hooper, 2000; Kaynak, Kucukemiroglu, \& Hyder, 2000; Opoku \& Akorli, 2009; Zhou \& Hui, 2003). The first reason is because foreign products usually have better quality when compared to domestic ones. The second reason is that products imported from abroad carry several symbolic values which domestic products do not have (e.g., luxury, prosperity, status and western style).

However, due to the small market size, the population's weak purchasing power, uncertain demands and a lack of adequate legal system (Ahmadi, Iravani, \& Mamani, 2015; Chang, 1993; Chow, 2011), many foreign companies may resort to setting up authorised distribution channels for their products to be sold in developing countries. This condition thus gives rise to grey or parallel imports. Nevertheless, with the strong support from the public, original trademark owners thus become "free riders" of all the efforts imposed by parallel importers (Chang, 1993). Specifically, original trademark owners' image and reputation are projected even before they make any official attempt to enter such markets. This is especially true if consumers are satisfied with the parallel products. Otherwise, future businesses of the rightful owners may be affected by the current uncontrolled negative incidents caused by unsafe or damaged products, no-service and warranty contracts, and inadequate manuals, among many others (Mathur, 1995).

In the Asian context, several research on parallel imports have been conducted in Taiwan and China. It was found that Taiwanese consumers are well-informed about parallel imports (Chang, 1993). Price-sensitive consumers chose parallel goods because their prices are cheaper when compared to those of non-parallel goods. However, variety-seeking consumers went to such markets to find something different and interesting while quality-sensitive consumers chose such markets to purchase expensive and high-quality products. In particular, 
Taiwanese customers' awareness of price-quality relationship and risks was found to significantly and negatively affect their attitude towards parallel imports (Huang, et al., 2004). In the context of China, it was observed that the Chinese consumers' perception of product quality had significantly influenced their intention to buy both the grey and legally authorised products. However, impact on grey goods was stronger (Liu et al., 2012). Generally, those who wanted to buy foreign products were highly loyal to brands. They were conscious of quality and fashion, and they also shopped on a monthly basis. Otherwise, those who preferred domestic goods were found to be price conscious and also overwhelmed by choice (Wang, Siu, \& Hui, 2004).

Similar to other developing countries, the parallel import and grey market in Vietnam is a prevailing issue. There are licensed parallel import activities such as pharmaceuticals besides grey parallel importations of high-tech products (Kuanpoth, 2007; Tuoi Tre News, 2014b). Although Vietnam is a member of the World Trade Organisation and it has signed many bilateral and multilateral trade agreements with other countries, grey parallel imports seem to be out of the official hold of the country (Harris, 2015). Foreign companies have noticed that the size of the grey market in Vietnam is several times larger than that of the official market. Thus, they are trying to deal with the issue by restructuring their activities in Vietnam (Vietnam Investment Review, 2012). Vietnamese consumers, on the other hand, are happy with the arrival of foreign brands (Ito, 2016). The great consumer demand has fuelled the booming of the grey market which may not carry protection for consumers.

\section{Research Methodology}

\subsection{Interview Questions}

Given the exploratory nature of this study, a qualitative method was adopted and a semi-structured interview (Richardson, Dohrenwend, \& Klein, 1965; Rubin \& Rubin, 1995) was conducted to gather data so as to fulfil the aim of the study. The interview questions (see Appendix) were prepared specifically for this study. They were based on the three theoretical frameworks encompassing social media usage, $\mathrm{C} 2 \mathrm{C}$ business and parallel imports (Decrop, 1999). Each major research issue was simultaneously asked from three different perspectives. By doing so, the interview questions were centred around the focus of the study. In other 
words, only relevant questions were asked so as to minimise interview time. The responses were cross-validated with the interviewees during the interview so as to ensure data reliability.

Prior to the interview, the questions were assessed and evaluated by an independent Vietnamese researcher who majors in marketing. Based on the feedback, minor adjustments were made to the questions to clarify the concepts used. This approach reflects a researcher-based triangulation method (Decrop, 1999).

\subsection{Sampling Procedure}

In the context of Vietnam, grey or parallel imported products come mainly from America, Australia, France, Japan, Korea and Thailand. Among these countries, Japan is one of the nearest to Vietnam (approximately 5 hours on direct flights) and it is also one of the main migration destinations of Vietnamese people (Ministry of Foreign Affairs of Vietnam, 2012). The Vietnamese make-up a remarkable proportion of the foreigner population of this country (Nippon Communications Foundation, 2016). In line with this, Japanese retailers (e.g., Aeon, Takashimaya and Seven Eleven) have been implementing more plans and undertakings to enter the Vietnamese market as compared to their counterparts from other countries (Nguyen \& Yui, 2016). Taking such factors into consideration, Japan was thus selected to be the original market of the parallel goods in this study.

The sampling procedure then began with the selection of a gatekeeper, or a Facebook-based grey or parallel products provider. The procedure was carried out with the help of the Facebook search engine, and "hàng xách tay Nhật" (unofficial parallel imported products from Japan) was used as the keyword. The provider that had the biggest number of "likes" (more than 50,000 as of mid-2016) was then contacted. As a result, the researcher was allowed to approach the customers of this provider. Following this, the researcher sent the interview questions to the provider for approval. The two parties also discussed the method, time and place of the interviews. Accordingly, direct interviews (semistructured individual interviews) were initiated in the last week of December 2016 (when a promotion campaign was scheduled) at a showroom of the provider in Hanoi, the capital city of Vietnam.

Since this study is theory-based, the sample size can be predetermined. Following Francis et al. (2010), and Guest, Bunce and Johnson (2006), a sample of 13 was considered appropriate. However, to reach 
the point of data saturation (i.e., no new information can be generated) at the 13th interview (Saumure \& Given, 2008), several requirements need to be fulfilled. For instance, it was requested that: (1) the domain of the inquiry is concentrated, (2) the quality of the data is high, and (3) the sample is not too heterogeneous (Guest, et al., 2006). Due to its design, the first requirement of this study has been fulfilled (i.e., the interview questions). To satisfy the second requirement, the researcher trained himself to be familiar with the qualitative research method and to obtain relevant background knowledge in psychology. The third requirement could be fulfilled by targeting a relatively homogeneous sample of married females who were between the age of 20 and 40 . This population, according to the statistics provided by Facebook for Business (2015), forms the majority of Facebook users in Vietnam. However, when looking at their profile as illustrated in Table 1, the actual sample can also be considered as relatively diverse.

Table 1. Profile of the Participants

\begin{tabular}{rcll}
\hline Participant & Age & Field of Occupation & Marital Status \\
\hline 1 & 29 & Freelance & Married \\
2 & 29 & Accounting & Married \\
3 & 33 & Pharmacy & Married \\
4 & 36 & Bank + Supermarket & Married \\
5 & 25 & Bank & Unmarried \\
6 & 28 & Business & Unmarried \\
7 & 35 & Police & Married \\
8 & 40 & Army & Married \\
9 & 36 & Housewife & Married \\
10 & 32 & Office & Married \\
11 & 24 & Business & Unmarried \\
12 & 28 & Foreign embassy & Unmarried \\
13 & 36 & Pharmacy & Married \\
\hline
\end{tabular}

A semi-structured interview was then conducted during the last week of December 2016 and the first week of January 2017 at the showroom of the abovementioned gatekeeper. Specifically, the researcher visited the showroom at a random hour on a given day within the given period. All the guests who came to the showroom during the time when the researcher was present were considered as targets of the interview $($ minimum $=0$; maximum $=5)$. The recruitment was then conducted 
with the help of the showroom staff. After the transaction with a certain female customer was completed, the staff introduced the research to the customer who was then asked if she would like to participate in the interview. If the customer agreed, she was directed to the researcher to hear more details and to provide the necessary information. This procedure was repeatedly undertaken until the thirteenth and final interview was concluded (quota sampling) (Robinson, 2014). The participation of all the interviewees was on a voluntary basis. However, each participant was given a small gift (approximately 10 US dollars) as part of the promotion campaign of the showroom.

\subsection{Data Collection and Analysis}

All the interviews were conducted in Vietnamese and recorded using a voice recorder. Each interview lasted for approximately 12.35 minutes. This length of interview was not too short when two elements were taken into account. First, the questions concentrated on the research. Second, Vietnamese is a monosyllabic language (Andersen, 1995). Observations were also conducted for each of the participants (from when the participant entered the showroom and began her talk with the showroom staff to when the staff introduced the research to her). Prior to the interview, a warm-up session was conducted so as to ease the interaction between the researcher and the participant. All the significant pre-interview observations were documented into a journal and these were later cross-checked with the interview responses for validation purposes. This approach is regarded as data triangulation (Decrop, 1999) and it helped to improve the quality and validity of the interviews (Guest, et al., 2006).

The contents of the interviews were later transcribed on a Word file and they were then content analysed (Elo \& Kyngäs, 2008). Since there was no predetermined coding scheme, the analysis was inductive. However, the purpose of the analysis was to extract responses that could fulfil the aim of the current study. Thus, the analysis had some deductive aspect.

The contents of the interview were manually analysed following several steps. First, the researcher read the interview transcriptions and took note of the responses for the research questions in each interview session (i.e., why they buy and how they make their purchases). This procedure was undertaken twice to ensure intra-coder reliability (Given, 2008). An Excel file was employed to manage the coding contents. 
Second, the interview transcriptions were sent to a second independent Vietnamese researcher who majors in service marketing to be cross-analysed using the same analysis method (Elo \& Kyngäs, 2008). The independent analyst also worked on the data twice. After that, the two analysts compared their results and identified the differences. The differences which occurred due to the miscounting or misinterpretation of either analyst were addressed through direct discussion until a final agreement was reached. The consent between the two analysts served as the inter-coder reliability of the analysis (Given, 2008).

Third, the two analysts worked together to identify the themes (categories) and the subcategories hidden among the responses. Each subcategory houses similar explicit opinions about a theme or category (Braun \& Clarke, 2006). The agreement between the two analysts served as the criterion of inter-coder reliability (Given, 2008). As a result of this undertaking, the responses indicating why customers buy were grouped into three categories: utilitarian, hedonic and symbolic values of the products and/or purchase process. However, since there was only one hedonism-oriented reason (enjoyment) for buying, which was an induced product of a utility-oriented one (ease and convenience), it was included under the utilitarian category. Responses catering to the second aim of how customers made their purchases were then placed into four categories: information searching, selection of products, selection of sellers and the buying process. An additional independent category, concerns and risks, was also noted and this was related to both why and how customers make their purchases.

Finally, all the responses and quotations made in Vietnamese were translated into English by the researcher. The process was supervised by a third independent researcher who is fluent in both languages so as to ensure the correctness of the translations.

\section{Findings}

\subsection{The Reasons for Buying "hàng xách tay"}

Analysis of the responses related to their reasons for buying unofficial parallel imported products (UPIPs) of Vietnamese consumers are detailed in Table 2. Specifically, the UPIPs helped to satisfy Vietnamese customers' needs of quality and trendy products that the domestic market cannot provide (Chang, 1993; Hooper, 2000; Kaynak, et al., 2000; Opoku \& Akorli, 2009). This reflects the utilitarian value of the UPIPs 
Table 2: Reasons for Buying UPIP

\begin{tabular}{|c|c|c|c|c|c|c|c|c|c|c|c|c|c|c|}
\hline \multirow{2}{*}{ Reasons } & \multicolumn{14}{|c|}{ Participant } \\
\hline & 1 & 2 & 3 & 4 & 5 & 6 & 7 & 8 & 9 & 10 & 11 & 12 & 13 & Total \\
\hline \multicolumn{15}{|c|}{ Reasons Related to Utilitarian and Hedonic Values } \\
\hline 1. Better quality & $x$ & $\mathrm{x}$ & & $x$ & $x$ & & $x$ & $x$ & $x$ & $\mathrm{x}$ & $\mathrm{x}$ & $x$ & $x$ & 11 \\
\hline $\begin{array}{l}\text { 2. Affordable } \\
\text { price }\end{array}$ & $x$ & $x$ & $x$ & $x$ & $x$ & & $x$ & & $x$ & $x$ & & & $x$ & 9 \\
\hline $\begin{array}{l}\text { 3. Convenience } \\
\text { and ease }\end{array}$ & & $x$ & & & & $x$ & $x$ & $x$ & $x$ & $x$ & $x$ & $x$ & $x$ & 9 \\
\hline $\begin{array}{l}\text { 4. Authenticity } \\
\text { and originality }\end{array}$ & $x$ & $x$ & & & $x$ & & & $x$ & $x$ & & & $x$ & & 6 \\
\hline 5. Unavailability & $x$ & & & & & $x$ & & & & $x$ & & & $x$ & 4 \\
\hline 6. Local products & & $x$ & & $x$ & & & & & & & $x$ & $x$ & & 4 \\
\hline $\begin{array}{l}\text { 7. Beautiful and } \\
\text { updated products }\end{array}$ & & & $x$ & & & & & $\mathrm{x}$ & & & & & $x$ & 3 \\
\hline $\begin{array}{l}\text { 8. Don't know } \\
\text { about official } \\
\text { imported products }\end{array}$ & & & & & & & & & & & & $x$ & & 1 \\
\hline $\begin{array}{l}\text { 9. Good shape } \\
\text { and form }\end{array}$ & & $x$ & & & & & & & & & & & & 1 \\
\hline 10. Satisfaction & & & $x$ & & & & & & & & & & & 1 \\
\hline \multicolumn{15}{|c|}{ Reasons Related to Symbolic Values } \\
\hline 11. Brand names & & & & & $x$ & & & & & & $\mathrm{x}$ & & & 2 \\
\hline 12. Confidence & & & & $x$ & & & & & & & & & & 1 \\
\hline $\begin{array}{l}\text { 13. "Been to the } \\
\text { original country" } \\
\text { feeling }\end{array}$ & $x$ & & & & & & & & & & & & & 1 \\
\hline
\end{tabular}

(Koo, Kim, \& Lee, 2008). In addition, with the support of Facebook and other social media platforms, the purchase of the UPIPs has become enjoyable since the process is convenient and easy (Heinonen, 2011; Kim, et al., 2011; Kwon \& Wen, 2010; Lin \& Lu, 2011; Yeh, et al., 2012). This implies the hedonic value of their buying behaviour (Koo, et al., 2008). Moreover, it appears that using imported products makes Vietnamese consumers feel more confident due to their brand names. Further, by buying these UPIPs, Vietnamese consumers have a sense of having been to the country of origin. These reasons indicate the symbolic values of the UPIPs (Zhou \& Hui, 2003). 
More specifically, 84.6 per cent (eleven out of thirteen participants) stated that the quality of imported products is better than that of domestic products. The participants buy these UPIPs because they were unable to find similar products in the domestic market, or they were not aware of the official distributors. Further, Vietnamese consumers regard the products obtained through this channel as authentic, original and affordable. They also have a sense of possessing the latest products (e.g., fashion) almost at the same time as consumers in the country of origin. They would not be able to enjoy this sense of possession if they had to go through the official importers.

Vietnamese consumers were especially aware of the true origin of the products purchased with 30.8 per cent (four out of thirteen participants) stating that they bought the UPIPs because these products were made by the country of origin for the local market. For example, Japanese cosmetics might be made in Japan and/or in a third country (e.g., X) and Vietnamese consumers preferred the made-in-Japan products to those made-in-X. Despite the fact that these products were made by the same company using the same technology and/or formulas, Vietnamese consumers believed more widely that the former was better. This belief not only applies to cosmetics made in Japan but also to other products such as Thai electronic goods (Voice of Vietnam, 2016). Some examples of their interviews are extracted for illustrations.

UPIPs are better in quality compared to products sold in the local market. If the UPIPs are authentic, their usability is better. (Participant 8; utilitarian-oriented reason)

Shopping on Facebook is very convenient... Information [on Facebook] is abundant and updated. It is ... very entertaining. (Participant 6; hedonism-oriented reason)

I am not crazy about foreign products, but if I have to spend a lot of money, I will definitely choose the brand-name products. Otherwise, I will buy made-in-Vietnam products to use for daily purposes. (Participant 5; symbolism-oriented reason)

\subsection{The Process of Buying "hàng xách tay" on Facebook}

\subsubsection{Information Searching}

Vietnamese consumers tend to use different approaches to make their online purchases (Table 3). On the one hand, they used word-of-mouth from friends and acquaintances as their major source of information for 
Table 3: Information Sources

\begin{tabular}{|c|c|c|c|c|c|c|c|c|c|c|c|c|c|c|}
\hline \multirow{2}{*}{\multicolumn{2}{|c|}{ Information Sources }} & \multicolumn{13}{|c|}{ Participants } \\
\hline & & 1 & 2 & 3 & 4 & 5 & 6 & 7 & 8 & 9 & 10 & 11 & 1213 & Total \\
\hline \multirow[t]{3}{*}{ Organic } & Friends & & & $x$ & & & & & & $x$ & $x$ & & $x$ & 4 \\
\hline & $\begin{array}{l}\text { Social media } \\
\text { networks }\end{array}$ & $x$ & & & & & & & $x$ & & & & $x$ & 3 \\
\hline & $\begin{array}{l}\text { Reviews and } \\
\text { comments }\end{array}$ & $x$ & & & & & & & $x$ & & & & & 2 \\
\hline \multirow[t]{3}{*}{ Induced } & $\begin{array}{l}\text { Direct talks } \\
\text { and consulta- } \\
\text { tion with sellers }\end{array}$ & & & $x$ & & & & & & & & $\mathrm{x}$ & & 2 \\
\hline & $\begin{array}{l}\text { Sellers' } \\
\text { advertisements }\end{array}$ & & & $x$ & & & & & & & & & & 1 \\
\hline & $\begin{array}{l}\text { Sellers' } \\
\text { Facebook }\end{array}$ & & & $x$ & & & & & & & & & & 1 \\
\hline \multirow[t]{2}{*}{ Others } & The Internet & & & & $x$ & & & & & & & & & 1 \\
\hline & Google & & & & & & $x$ & & & & & & & 1 \\
\hline
\end{tabular}

the UPIPs and their dealers. These sources provided them with organic yet subjective references (Gartner, 1994) as to what to buy and from whom to buy. In the pre-Facebook era, consumers used actual wordof-mouth but presently, Facebook has endorsed the giving and taking of electronic word-of-mouth recommendations through its interactive environment. A consumer may know about a product and/or a seller when he/she is tagged by friends or suggested by Facebook based on his/her past activities. Such consumers can refer to the reviews and comments posted on the Facebook page of a particular site so as to decide on their own purchase behaviour (Amblee \& Bui, 2012; Phang, et al., 2013). These consumers may also use their Facebook or other Internetbased engines (e.g., Google) to conduct an active search of the relevant products and/or sellers (a mix of organic and induced information). One of the participant's response is provided as illustration.

Before buying any products, I have to search the Facebook page of the seller for information. I will buy the products that my friends have already bought and used. I will read my friends' comments before buying. I will not buy a product that none of my friends has bought and used. (Participant 9) 
On the other hand, Vietnamese consumers do not overlook the induced sources of information such as advertisements and Facebook pages of providers (Gartner, 1994). In this regard, the interactive environment of Facebook has been actively used by both the involved parties. Specifically, sellers and buyers use this platform to ask and answer the inquiries of each other regarding the products and the buying process. This function has helped to narrow down the spatial and geographical distance between sellers and buyers. It has also helped to create a mutual understanding and trust between both parties besides facilitating the actual transactions (Ariely \& Simonson, 2003; GrabnerKraeuter, 2002; Hassanein \& Head, 2007). Response from participant 11 illustrates this point.

I will not only refer to the information posted on the Facebook page, but I will chat directly with the seller. (Participant 11)

\subsubsection{Selection of Products}

Vietnamese consumers also used a number of approaches to make their purchases. They seemed to rely heavily on their own experiences as well as the experiences of their acquaintances when choosing products as illustrated in Table 4.

Most of the participants mentioned that they tried the new products and/or compared them with those they have used before making their purchases. However, it appears that they may also rely on their friends or other people when buying products. This behaviour characterises the psychology of the crowd of Vietnamese consumers, with the most salient example being the stock market (Stage, 2013; Ton \& Dao, 2014). Responses from the participants are provided as illustrations.

I read the reviews before buying any products. I also try a new product and compare it with the one that I used before. If that product is as good as or better than the old one, I will continue to use it. If not, I will discontinue. (Participant 2)

The first product that I bought on Facebook was a floor sweeper. It was a very popular product at that time. (Participant 9)

It also seems that Vietnamese consumers were conscious of what they buy and how they buy the products. They preferred products with low values and do not harm their health (e.g., no-food policy) and also do not involve a guarantee policy. Nonetheless, the definition of low 
Table 4: Product Selection Criteria

\begin{tabular}{|c|c|c|c|c|c|c|c|c|c|c|c|c|c|c|c|}
\hline \multirow{2}{*}{\multicolumn{2}{|c|}{ Product Selection Criteria }} & \multicolumn{14}{|c|}{ Participant } \\
\hline & & 1 & 2 & 3 & \multirow[t]{2}{*}{4} & \multirow[t]{2}{*}{5} & \multirow[t]{2}{*}{6} & \multirow[t]{2}{*}{7} & \multirow[t]{2}{*}{8} & \multirow{2}{*}{$\frac{9}{x}$} & \multirow[t]{2}{*}{10} & \multirow{2}{*}{$\frac{11}{x}$} & \multirow{2}{*}{$\frac{12}{x}$} & \multirow{2}{*}{13} & \multirow{2}{*}{$\frac{\text { Total }}{6}$} \\
\hline $\begin{array}{l}\text { Self- } \\
\text { experience }\end{array}$ & $\begin{array}{l}\text { Compare with } \\
\text { old products }\end{array}$ & & $x$ & $x$ & & & & & & & & & & & \\
\hline & $\begin{array}{l}\text { Try before } \\
\text { buying more }\end{array}$ & & $x$ & $\mathrm{x}$ & & & & & & & $x$ & & & & 3 \\
\hline \multirow[t]{3}{*}{$\begin{array}{l}\text { Peer } \\
\text { experience }\end{array}$} & $\begin{array}{l}\text { Buy products } \\
\text { used by friends }\end{array}$ & & & & & & & & & $x$ & & & & $x$ & 2 \\
\hline & $\begin{array}{l}\text { Follow the } \\
\text { current trends } \\
\text { or fashions }\end{array}$ & & & & & & & & & & $x$ & & & & 1 \\
\hline & $\begin{array}{l}\text { Buy products } \\
\text { purchased by } \\
\text { many people }\end{array}$ & & & & & & & & & & & $x$ & & & 1 \\
\hline \multirow[t]{3}{*}{$\begin{array}{l}\text { Product } \\
\text { value }\end{array}$} & $\begin{array}{l}\text { Buy products } \\
\text { with low } \\
\text { values }\end{array}$ & & & $x$ & & & & & & & & & & $x$ & 2 \\
\hline & $\begin{array}{l}\text { Buy products } \\
\text { which are } \\
\text { harmless to } \\
\text { health }\end{array}$ & & & $x$ & & & & & & & & & & & 1 \\
\hline & $\begin{array}{l}\text { Buy products } \\
\text { which do not } \\
\text { involve a } \\
\text { guarantee }\end{array}$ & & & & & & & & & & & & & $x$ & 1 \\
\hline
\end{tabular}

value appears to differ among the participants. Participant 11 used the 2 million Vietnamese Dong (approximately $90 \mathrm{USD}$ ) as the cut-off point while participant 13 considered the 10 million Vietnamese Dong as threshold. Considering the profile of these two participants (Table $1)$, there is a potential correlation between a respondent's subjective perception of economic value and her sociodemographic characteristics as observed by Furnham (1996).

\subsubsection{Selection of Sellers}

When choosing the UPIPs, Vietnamese consumers not only buy products but also use the shipping services from the country of origin to their place of residence (Table 5). In this regard, it can be said that Vietnamese 
Table 5: Seller Selection Criteria

\begin{tabular}{|c|c|c|c|c|c|c|c|c|c|c|c|c|c|c|c|}
\hline \multirow{2}{*}{\multicolumn{2}{|c|}{ Seller Selection Criteria }} & \multicolumn{14}{|c|}{ Participant } \\
\hline & & 1 & 2 & 3 & 4 & 5 & 6 & 7 & 8 & 9 & 10 & 11 & 12 & 13 & Total \\
\hline \multirow[t]{4}{*}{$\begin{array}{l}\text { Evidence- } \\
\text { based }\end{array}$} & $\begin{array}{l}\text { Sellers have } \\
\text { many reviews } \\
\text { and comments }\end{array}$ & & $x$ & & & & $x$ & & $x$ & $x$ & $x$ & & & $x$ & 6 \\
\hline & $\begin{array}{l}\text { Accredited } \\
\text { sellers }\end{array}$ & & $x$ & & & $\mathrm{x}$ & $x$ & $x$ & $x$ & & & & & & 5 \\
\hline & $\begin{array}{l}\text { Sellers have } \\
\text { showrooms }\end{array}$ & & $x$ & & & & & $x$ & $x$ & & & $x$ & & & 4 \\
\hline & $\begin{array}{l}\text { Sellers have } \\
\text { staff }\end{array}$ & & & & & & & $x$ & & & & & & & 1 \\
\hline \multirow[t]{2}{*}{$\begin{array}{l}\text { Relation- } \\
\text { ship- } \\
\text { based }\end{array}$} & $\begin{array}{l}\text { Products sold } \\
\text { by friends } \\
\text { and/or } \\
\text { acquaintances }\end{array}$ & $x$ & & & $x$ & $x$ & $x$ & $x$ & & & & & & & 5 \\
\hline & $\begin{array}{l}\text { Buy through } \\
\text { intermediaries }\end{array}$ & & & $x$ & & & & & & & & & & & 1 \\
\hline \multirow[t]{2}{*}{ Others } & $\begin{array}{l}\text { There are } \\
\text { many dealers }\end{array}$ & $x$ & & & & & & & & & & & & & 1 \\
\hline & $\begin{array}{l}\text { There is } \\
\text { competition } \\
\text { but not too } \\
\text { much }\end{array}$ & & & & $\mathrm{x}$ & & & & & & & & & & 1 \\
\hline
\end{tabular}

consumers choose to do their transactions with those whom they know such as friends and/or acquaintances. In addition, they preferred those dealers who have received many positive reviews and comments and those with physical showrooms and staff. However, Vietnamese consumers were aware that there is a wide range of providers in the UPIP market. Thus, they would only select the most accredited sellers to deal with. This implies that the role of the reviews, comments, showrooms and staff as noted, and the relationship of the parties concerned, cannot be overlooked in the whole process. Some responses were drawn from the participants to support this claim.

The second reason why I make a purchase on Facebook is because the product is sold my friends or acquaintances. I am assured when buying their products. (Participant 1 ) 
I only buy UPIPs at reliable shops. I will question those very cheap products. Why are the prices too low despite having the same origin? There is competition, but the competition is not fierce. (Participant 4)

\subsubsection{Buying Process}

Table 6 displays the buying process of the Vietnamese consumers which involved several steps commencing from the pre-buying stage until the delivery stage. It appears that Vietnamese consumers would go to the UPIP dealers when they were unable to buy the products that they wanted on their own or when they could not get their friends in the country of origin to help them make such a purchase. They were aware that these products were usually bought during sales campaigns. This reason, together with the fact that the products were bought outside of Vietnam, takes product guarantee off the UPIPs. However, many participants mentioned that they were not concerned about product guarantees or how these products were brought into Vietnam although some mentioned the air transport method. When making a deposit or payment, they refrained from using the escrow service but instead used cash or bank transfers. One participant mentioned that she kept the screen shot of her transaction as the invoice of the deposit. Later when receiving their orders, these buyers would check the bills, barcodes and tags of the products to verify whether they were authentic and original or not. However, this was confined to only 38.5 per cent (only five out of thirteen participants). Some of their responses are provided for illustrations.

I choose the product then send the link to the dealer. The dealer then calculates the price. For example, the official Vietnamese Dong - US Dollar rate is 22.000. Yet, the dealer's rate may be 23.000. The dealer will also add the purchase fee to the total price. (Participant 5)

Actually I don't care about the shipping method. I usually check the barcode of the product. Sometimes I check its bill. I rely on the barcode and the bill. (Participant 6)

Yes, I do care about product origin. First, a product must have its bill. Second, I must be able to check its code. (Participant 4)

\subsection{Concerns and risks}

As can be noted from Table 7, the participants mentioned some of their concerns when buying the UPIPs from Facebook. These concerns include no trial basis, wrong sizes, unauthentic products or unoriginal products, 
Table 6: The Purchase Process

\begin{tabular}{|c|c|c|c|c|c|c|c|c|c|c|c|c|c|c|c|}
\hline \multirow{2}{*}{\multicolumn{2}{|c|}{ Purchase Process }} & \multicolumn{14}{|c|}{ Participant } \\
\hline & & 1 & 2 & 3 & 4 & 5 & 6 & 7 & 8 & 9 & 10 & 11 & 12 & 13 & Total \\
\hline \multirow[t]{2}{*}{ Pre-buy } & $\begin{array}{l}\text { Choose product } \\
\text { links then send to } \\
\text { the dealers }\end{array}$ & & & & & $x$ & & & & & & & & & 1 \\
\hline & $\begin{array}{l}\text { Study the guar- } \\
\text { antee policies }\end{array}$ & & & $x$ & & & & & & & & & & & 1 \\
\hline \multirow[t]{4}{*}{ Paying } & $\begin{array}{l}\text { Pay on the rate } \\
\text { defined by sellers }\end{array}$ & & & & & $x$ & & & & & & & & & 1 \\
\hline & Pay shipping fee & & & & & $x$ & & & & & & & & & 1 \\
\hline & $\begin{array}{l}\text { Pay deposits for } \\
\text { products with high } \\
\text { values }\end{array}$ & & & & & $x$ & & & & & & & & & 1 \\
\hline & Pay on delivery & & & & & $x$ & & & & & & & & & 1 \\
\hline \multirow[t]{5}{*}{ Shipping } & $\begin{array}{l}\text { Don't care how } \\
\text { products are carried } \\
\text { to Vietnam }\end{array}$ & & & & & & $x$ & & & $\mathrm{x}$ & $x$ & & & $\mathrm{x}$ & 4 \\
\hline & $\begin{array}{l}\text { Ask friends to bring } \\
\text { the products to } \\
\text { Vietnam }\end{array}$ & & & & & & & $x$ & & & & & $x$ & & 2 \\
\hline & $\begin{array}{l}\text { Bought products } \\
\text { and brought them } \\
\text { back to Vietnam on } \\
\text { one's own }\end{array}$ & & & & & & & $x$ & & & & & & & 1 \\
\hline & $\begin{array}{l}\text { Study the shipping } \\
\text { methods }\end{array}$ & & $x$ & & & & & & & & & & & & 1 \\
\hline & $\begin{array}{l}\text { By means of air } \\
\text { transport }\end{array}$ & & & & & $x$ & & & & & & & & & 1 \\
\hline \multirow{3}{*}{$\begin{array}{l}\text { Upon } \\
\text { delivery }\end{array}$} & Check product bills & & $x$ & & $x$ & $x$ & $x$ & & $x$ & & & & & & 5 \\
\hline & $\begin{array}{l}\text { Check product } \\
\text { barcodes }\end{array}$ & & & & $x$ & & $x$ & & & & & & & & 2 \\
\hline & Check product tags & & & & & $x$ & & & & & & & & & 1 \\
\hline \multirow[t]{2}{*}{ Post-buy } & $\begin{array}{l}\text { There is no guar- } \\
\text { antee if the products } \\
\text { are sale-off items }\end{array}$ & & & & & $x$ & & & & & & & & $x$ & 2 \\
\hline & $\begin{array}{l}\text { Products sold in the } \\
\text { Vietnam market are } \\
\text { sale-off items }\end{array}$ & & & & & $x$ & & & & & & & & & 1 \\
\hline
\end{tabular}


Table 7: Customer Concerns

\begin{tabular}{|c|c|c|c|c|c|c|c|c|c|c|c|c|c|c|c|}
\hline \multirow{2}{*}{\multicolumn{2}{|c|}{ Customer Concerns }} & \multicolumn{14}{|c|}{ Participants } \\
\hline & & 1 & 2 & 3 & 4 & 5 & 6 & 7 & 8 & 9 & 10 & 11 & 12 & 13 & Total \\
\hline \multirow[t]{8}{*}{ Product } & No prior try & & & $\mathrm{x}$ & & & $x$ & & & & & & $\mathrm{x}$ & $\mathrm{x}$ & 4 \\
\hline & Wrong sizes & $x$ & & $x$ & & & & & & & & & & & 2 \\
\hline & $\begin{array}{l}\text { Low-quality and/ } \\
\text { or inauthentic } \\
\text { products }\end{array}$ & & $x$ & & & & $x$ & & & & & & & & 2 \\
\hline & $\begin{array}{l}\text { Product } \\
\text { authenticity }\end{array}$ & & & & & $x$ & & & $x$ & & & & & & 2 \\
\hline & Fake products & & & & $x$ & & & & & $x$ & & & & & 2 \\
\hline & Product origin & & & & & & $x$ & & & & & & & & 1 \\
\hline & Expiry date & & & & & & & & $x$ & & & & & & 1 \\
\hline & $\begin{array}{l}\text { Non-local } \\
\text { products }\end{array}$ & & & & & & & & $x$ & & & & & & 1 \\
\hline \multirow[t]{2}{*}{ Seller } & Trust the dealers & $x$ & & & & & & $x$ & & $x$ & & & & & 3 \\
\hline & $\begin{array}{l}\text { Disagreeable } \\
\text { sellers }\end{array}$ & & & & & & & & & $x$ & & & & & 1 \\
\hline \multirow{3}{*}{$\begin{array}{l}\text { Financial \& } \\
\text { Transaction }\end{array}$} & Expensive & & & & & & & & & & & & $x$ & $\mathrm{x}$ & 2 \\
\hline & Waiting time & & & & & & & & & & & & $x$ & & 1 \\
\hline & Fake comments & & & & & & & & & $x$ & & & & & 1 \\
\hline \multirow[t]{2}{*}{ Others } & $\begin{array}{l}\text { Expect and rely } \\
\text { on luck }\end{array}$ & $x$ & & & & & & & & & $x$ & & & & 2 \\
\hline & Accept the risks & & & & & & & & & & & & & $\mathrm{x}$ & 1 \\
\hline
\end{tabular}

low quality products or fake products, and disagreeable sellers, among others. Their concerns were particularly related to online shopping in general (Biswas \& Biswas, 2004; Forsythe, Liu, Shannon, \& Gardner, 2006). However, the participants were more concerned about the products and sellers' risks than the financial transactions or transaction risks (e.g., expensiveness, waiting time and inaccurate information). Some participants also stated that they trusted the sellers so they do not have any worries while other participants may rely on their luck when buying the UPIPs on Facebook. Some responses are provided as evidence.

I cannot see the products. Sometimes the size or number lof a piece of clothing] is mismatched. Yet, I haven't got any bad products when 
shopping on Facebook. That may be due to my shopping method. I make a purchase based upon my friends' recommendations. (Participant 3)

The origin of the domestic products is unreliable. Sellers may sell lowquality products together with high-quality products. The origin of the UPIPs, however, is apparent. I know and trust the sellers so I buy their products. (Participant 9)

"Hàng xách tay" usually are expensive but they are high quality. For example, I paid 2 million Vietnamese Dong for a frying pan. It is costly yet acceptable because the quality is good. (Participant 13)

\section{Discussions}

From the responses generated and analysed, the findings indicated that a proportion of Vietnamese consumers have high demands for the UPIPs. In this regard, they shared the same opinion with their counterparts in other developing countries when rejecting home products (Hooper, 2000; Kaynak, et al., 2000; Opoku \& Akorli, 2009). However, Vietnamese domestic product makers cannot blame their domestic customers totally for their low trust and pride in purchasing homemade products. Vietnam has run its "Vietnamese High-Quality Goods" programme for more than 20 years (Viet Nam News, 2017). Yet domestic suppliers are still not qualified to enter the supply chain of big producers like Samsung (Tuoi Tre News, 2014a) while its automobile industry has not made any significant development thus far (Vietnamnet, 2017). Consequently, Vietnamese consumers have to find other channels to obtain the products that they need but are not available in the local market. Buying the UPIPs, for example, is such an alternative.

In addition, Vietnamese consumers preferred the UPIP sellers who were known to them and/or their acquaintances. As buyers and users, they have also become familiar with the user-generated contents (i.e., customer reviews and comments) (Yang \& Fang, 2004) while actively participating in the creation and use of such contents on the transaction platforms of the UPIPs (e.g., Facebook). Nevertheless, Vietnamese consumers are aware of the tangible aspect of the sellers' services (Shostack, 1982). Specifically, 30.8 per cent (four out of thirteen participants) mentioned that showrooms served as one of the criterions to judge if a seller is reliable or not. This point implies two things. In one sense, many Vietnamese UPIP dealers are professionals because they know how to make their services more tangible and reliable (e.g., 
showrooms and staff) (de Vries, et al., 2012; Shen \& Bissell, 2013). In another sense, the Vietnamese UPIP market has gone through many stages of development in the past 40 years since the 1980s. The introduction of Facebook and other social media platforms, in particular, has brought the on-ground market to the online environment. It is that interactive environment that has propelled many UPIP sellers to ground their services once more even though the grounding is an expansion of the online activity. The latter is still the dominant transaction platform for many providers.

Moreover, a majority of the participants did not express any particular problem with regards to their previous transactions. They seemed to find it convenient and easy to buy the UPIPs on Facebook. In other words, Facebook has added some hedonic values to the transactions which traditionally only relate to the utilitarian and symbolic values of the UPIPs. The fact that Vietnamese consumers felt relatively safe when buying the UPIPs on Facebook can be explained by two observations. First, the Facebook-based market of the UPIPs in Vietnam was built and run based on trust among acquaintances (Grabner-Kraeuter, 2002; Hassanein \& Head, 2007; Jones \& Leonard, 2008). This trust has been established based on the experiences of the consumers and their friends and/or friends of friends. The reputation of the sellers also adds to the development of that trust (Biswas \& Biswas, 2004). Second, Vietnamese consumers are optimistic. They were ranked fourth globally in the first quarter of 2018 (Nielsen, 2018). Thus, it is understandable when Vietnamese consumers do not seem to have many big concerns when buying online in general and buying the UPIPs on Facebook in particular.

In summary, consumers go to the grey market to buy cheaper, higher quality and more trendy products which local producers and/ or distributors cannot make and/or provide (Malueg \& Schwartz, 1994; Richardson, 2002). Due to its nature, the grey market is a relatively closed one. In the case of Vietnam, these two characteristics are still prominent in the late 2010s. However, some developments in the grey market can also be detected. First, with the development of the Internetbased devices and applications, the grey market has partly been merged with the $\mathrm{C} 2 \mathrm{C}$ market and the e-commerce market. Second, by being highlighted on the social networking sites, the grey market has become an open market. However, due to certain reasons such as the lack of a strong and effective legal framework, this market is not yet an official one. Third, social media platforms have already been transformed into 
real shopping venues. Yet the SMB C2C market is still a small one since only private businesses are actually selling their products on these platforms. However, thanks to these initial undertakings, customers can presently enjoy a personalised service with many of their niche needs met satisfactorily.

\section{Implications}

The UPIP market in Vietnam is a trust-based one. Nevertheless, consumer trust, as a psychological phenomenon, is an unstable asset. The trust between buyers and sellers and between buyers and buyers have gradually been built and strengthened (and vice versa) after each transaction. There may be some unavoidable incidents (e.g., fake comments, disagreeable sellers and low quality and/or inauthentic products) but the invisible hand (Johnson, Price, \& Van Vugt, 2013) which is empowered by consumer reviews and comments will perform its function to expel the bad dealers from the market.

It is interesting to note that the legal owners of the UPIPs in the country of origin can profit from the current activities in the Vietnamese market. Specifically, the UPIP sellers, in order to make their businesses reliable and inviting, have already spread good word-of-mouth about the brand owners. Consequently, the image and reputation of the brand owners become established even before they actually enter the Vietnamese market. A market segment of potential consumers are already awaiting them. Therefore, legal brand owners should consider opening official stores in Vietnam so as to exploit the promise of a market whose spending power is the best in the Southeast Asian region (Nikkei, 2018). Nonetheless, Vietnamese consumers are realistic (e.g., pursuers of utilitarian values) although erratic (i.e., followers of crowd psychology). They are likely to turn their backs on the official providers if their expectations are not met, especially those involved with product categories, product origin and product prices. Therefore, a careful market research, and even a trial basis is necessary before any official entry initiatives are undertaken. Providers such as H\&M, Starbucks and Zara, for example, have invested in such careful steps when making their appearances in the Vietnamese market.

While buyers and brand owners have actually benefited from the UPIP market, the Vietnamese government seems to be aloof. Both the central and provincial authorities have stated that they wanted to tax Facebook-based businesses (Tuoi Tre News, 2017) yet no significant 
effort has been implemented. Consequently, the open UPIP market is not legally governed and has remained grey. If the Vietnamese government actually taxes these businesses, it needs to enact an e-commerce law, which is unavailable at the moment. Moreover, by taxing and making revenues from these markets, the government is unofficially but directly supporting the import of more consumer goods. This contradicts their official yet ineffective support for domestic production. This issue, unfortunately, is too big to be addressed by this paper. However, a non-tax policy which controls the import of illegal or harmful products (e.g., plants, meat products and drugs) is recommendable in this context. In addition, the introduction of an e-commerce law should be facilitated. Once the legal framework is established, protection to customer rights may properly help the UPIP market to perform its functions more responsibly.

\section{Conclusion, Limitations and Directions for Future Studies}

The Vietnamese UPIP market is no doubt a giant bazaar which partly contributes to the 4-million-USD e-commerce market of the country in 2015 (Tomiyama, 2016). This market is getting bigger because it can fulfil the diverse needs of Vietnamese consumers whose income has improved but whose needs are not satisfied. Vietnamese consumers also distinguished between made-by-the-country-of-origin and made-in-thecountry-of-origin products. There is a wide belief among Vietnamese consumers that the latter category is the better one. Furthermore, customers entered the market only after carefully consulting their own experiences and those of their acquaintances. In other words, they are self-educated customers. However, their self-education is limited to the buying and using of the UPIPs in Vietnam. They still lack the experience of buying and using the same products in the country of origin. Consequently, they may over-trust the sellers and be taken advantage of.

Being confined to only looking at Vietnamese consumers, this study bears some limitations. First, this study only captures the opinions of women in an urban area buying the UPIPs from Facebook. The male and rural consumers were not investigated. However, the findings may also reflect the opinions of other consumers as the female respondents had stated that they also buy for their family members including husbands and boyfriends. It is also likely that rural consumers may have a lower income level. Hence they would have a weaker market power and their opinions may be less significant. Second, this study focusses 
on the buyers' perspective of the UPIP transactions while the sellers' perspective was excluded. In this regard, it is possible that the sellers would have different responses for the same research issues. Third, this study only focusses on Vietnam as a developing country. Therefore, the activities of the Facebook-based UPIP market in other countries were overlooked.

Considering these limitations, some directions for future studies can be proposed. Specifically, researchers may examine the rural market of Vietnam to see how customers perceive and evaluate domestic and imported products. This will help both the local producers and the UPIP businesses in their market penetration and extension efforts. Researchers may also focus on the suppliers' side of the current UPIP market of Vietnam so as to understand why some suppliers became big and successful while others remained small and less successful. This will further enrich the literature of grey market in the era of the Internet and social media. Further, researchers may consider examining the same phenomenon in their home countries. The outcome generated can open a new line of comparative research on grey markets. This will be helpful towards the advanced preparation of new market entry and the penetration of international companies into new markets.

\section{References}

Ahmadi, R., Iravani, F., \& Mamani, H. (2015). Coping with gray markets: The impact of market conditions and product characteristics. Production and Operations Management, 24(5), 762-777. http://dx.doi.org/10.1111/ poms.12319

Alalwan, A.A., Rana, N.P., Dwivedi, Y.K., \& Algharabat, R. (2017). Social media in marketing: A review and analysis of the existing literature. Telematics and Informatics, 34(7), 1177-1190. http://dx.doi.org/10.1016/j.tele.2017.05.008

Altug, M.S., \& Sahin, O. (2018). Impact of parallel imports on pricing and product launch decisions in pharmaceutical industry. Production and Operations Management. http://dx.doi.org/10.1111/poms.12908

Amblee, N., \& Bui, T. (2012). Harnessing the influence of social proof in online shopping: The effect of electronic word of mouth on sales of digital microproducts. International Journal of Electronic Commerce, 16(2), 91-114. http://dx.doi.org/10.2753/JEC1086-4415160205

Andersen, T. (1995). Morphological stratification in Dinka: On the alternations of voice quality, vowel length and tone in the morphology of transitive verbal roots in a monosyllabic language. Studies in African Linguistics, 23(1), 1-63. 
Antia, K.D., Bergen, M.E., Dutta, S., \& Fisher, R.J. (2006). How does enforcement deter gray market incidence? Journal of Marketing, 70(1), 92-106. http:// dx.doi.org/10.1509/jmkg.2006.70.1.92

Antony, S., Lin, Z., \& Xu, B. (2006). Determinants of escrow service adoption in consumer-to-consumer online auction market: An experimental study. Decision Support Systems, 42(3), 1889-1900. http://dx.doi.org/10.1016/j. dss.2006.04.012

Ariely, D., \& Simonson, I. (2003). Buying, bidding, playing, or competing? Value assessment and decision dynamics in online auctions. Journal of Consumer Psychology, 13(1/2), 113-123.

Ayeh, J.K. (2015). Travellers' acceptance of consumer-generated media: An integrated model of technology acceptance and source credibility theories. Computers in Human Behavior, 48(July), 173-180. http:/ /dx.doi.org/10.1016/ j.chb.2014.12.049

Batra, R., Ramaswamy, V., Alden, D.L., Steenkamp, J.-B. E.M., \& Ramachander, S. (2000). Effects of brand local and nonlocal origin on consumer attitudes in developing countries. Journal of Consumer Psychology, 9(2), 83-95. http:/ / dx.doi.org/10.1207/S15327663JCP0902_3

Becherer, R.C., \& Halstead, D. (2004). Characteristics and internet marketing strategies of online auction sellers. International Journal of Internet Marketing and Advertising, 1(1), 24-37. http:/ / dx.doi.org/10.1504/IJIMA.2004.003688

Biswas, D., \& Biswas, A. (2004). The diagnostic role of signals in the context of perceived risks in online shopping: Do signals matter more on the web? Journal of Interactive Marketing, 18(3), 30-45. http://dx.doi.org/10.1002/ dir.20010

Braun, V., \& Clarke, V. (2006). Using thematic analysis in psychology. Qualitative Research in Psychology, 3(2), 77-101. http://dx.doi.org/10.1191/ 1478088706qp063oa

Carter, M., Tams, S., \& Grover, V. (2017). When do I profit? Uncovering boundary conditions on reputation effects in online auctions. Information $\mathcal{E}$ Management, 54(2), 256-267. http:/ / dx.doi.org/10.1016/j.im.2016.06.007

Chang, T.-Z. (1993). Parallel importation in Taiwan: A view from a newly emerged country and a comparative analysis. International Marketing Review, 10(6), 30-41. http:/ / dx.doi.org/10.1108/02651339310051605

Che, J.W.-S., Cheung, C.M.-K., \& Thadani, D.R. (2017). Consumer purchase decision in Instagram stores: The role of consumer trust. Proceedings of the 50th Hawaii International Conference on System Sciences (pp. 24-33). Honolulu, HI: Shidler College of Business, University of Hawaii at Manoa.

Chen, J.V., Su, B.-C., \& Widjaja, A.E. (2016). Facebook C2C social commerce: A study of online impulse buying. Decision Support Systems, 83(March), 57-69. http:/ / dx.doi.org/10.1016/j.dss.2015.12.008

Chow, D. (2011). Exhaustion of trademarks and parallel imports in China. Santa Clara Law Review, 51(4), 1283-1309. 
Cox, T., \& Park, J.H. (2014). Facebook marketing in contemporary orthodontic practice: A consumer report. Journal of the World Federation of Orthodontists, 3(2), 43-47. http:/ /dx.doi.org/10.1016/j.ejwf.2014.02.003

de Vries, L., Gensler, S., \& Leeflang, P. S.-H. (2012). Popularity of brand posts on brand fan pages: An investigation of the effects of social media marketing. Journal of Interactive Marketing, 26(2), 83-91. http://dx.doi.org/10.1016/j. intmar.2012.01.003

DeAndrea, D.C., Ellison, N.B., LaRose, R., Steinfield, C., \& Fiore, A. (2012). Serious social media: On the use of social media for improving students' adjustment to college. Internet and Higher Education, 15(1), 15-23. http:// dx.doi.org/10.1016/j.iheduc.2011.05.009

Decrop, A. (1999). Triangulation in qualitative tourism research. Tourism Management, 20(1), 157-161. http:/ / dx.doi.org/10.1016/S0261-5177(98)00102-2

Dijkmans, C., Kerkhof, P., \& Beukeboom, C.J. (2015). A stage to engage: Social media use and corporate reputation. Tourism Management, 47(April), 58-67. http://dx.doi.org/10.1016/j.tourman.2014.09.005

Ellison, N.B., Steinfield, C., \& Lampe, C. (2007). The benefits of Facebook "friends:" Social capital and college students' use of online social network sites. Journal of Computer-Mediated Communication, 12(4), 1143-1168. http:/ / dx.doi.org/10.1111/j.1083-6101.2007.00367.x

Ellison, N.B., Vitak, J., Steinfield, C., Gray, R., \& Lampe, C. (2011). Negotiating privacy concerns and social capital needs in a social media environment. In S. Trepte, \& L. Reinecke (eds.), Privacy Online (pp. 19-32). Berlin: Springer.

Elo, S., \& Kyngäs, H. (2008). The qualitative content analysis process. Journal of Advanced Nursing, 62(1), 107-115. http://dx.doi.org/10.1111/j.1365-2648. 2007.04569.x

Esper, T.L., Jensen, T.D., Turnipseed, F.L., \& Burton, S. (2003). The last mile: An examination of effects of online retail delivery strategies on consumers. Journal of Business Logistics, 24(2), 177-203. http://dx.doi.org/10.1002/ j.2158-1592.2003.tb00051.x

Facebook for Business. (2015, August 4). Vietnamese on Facebook: Mobile first, multi-screening and 'always on'. Retrieved from https://www. facebook.com/business/news/-Vietnamese-on-Facebook-Mobile-first-multiscreening-and-always-on

Forsythe, S.M., \& Shi, B. (2003). Consumer patronage and risk perceptions in Internet shopping. Journal of Business Research, 56(11), 867-875. http:// dx.doi.org/10.1016/S0148-2963(01)00273-9

Forsythe, S., Liu, C., Shannon, D., \& Gardner, L.C. (2006). Development of a scale to measure the perceived benefits and risks of online shopping. Journal of Interactive Marketing, 20(2), 55-75. http://dx.doi.org/10.1002/ dir.20061

Francis, J.J., Johnston, M., Robertson, C., Glidewell, L., Entwistle, V., Eccles, M.P., \& Grimshaw, J.M. (2010). What is an adequate sample size? Operationalising data saturation for theory-based interview studies. 
Psychology and Health, 25(10), 1229-1245. http://dx.doi.org/10.1080/ 08870440903194015

Furnham, A. (1996). Attitudinal correlates and demographic predictors of monetary beliefs and behaviours. Journal of Organizational Behavior, 17(4), 375-388. http://dx.doi.org/10.1002/(SICI)1099-1379(199607)17:4<375::AIDJOB767>3.0.CO;2-8

Gallini, N.T., \& Hollis, A. (1999). A contractual approach to the gray market. International Review of Law and Economics, 19(1), 1-21. http://dx.doi. org/10.1016/S0144-8188(98)00032-5

Gartner, W.C. (1994). Image formation process. Journal of Travel and Tourism Marketing, 2(2/3), 191-216. http://dx.doi.org/10.1300/J073v02n02_12

Given, L.M. (2008). The SAGE encyclopedia of qualitative research methods. Thousand Oaks, CA: SAGE.

Grabner-Kraeuter, S. (2002). The role of consumers' trust in online-shopping. Journal of Business Ethics, 39(1/2), 43-50. http://dx.doi.org/10.1023/ A:1016323815802

Guest, G., Bunce, A., \& Johnson, L. (2006). How many interviews are enough? An experiment with data saturation and variability. Field Methods, 18(1), 5982. http://dx.doi.org/10.1177/1525822X05279903

Han, S.-L., Nguyen, T.-P. T., \& Nguyen, V.A. (2016). Antecedents of intention and usage toward customers' mobile commerce: Evidence in Vietnam. Journal of Global Scholars of Marketing Science, 26(2), 129-151. http://dx.doi. org/10.1080/21639159.2015.1116796

Harris, D. (2015, June 20). How to protect your brand in Vietnam. China too. Retrieved http://www.chinalawblog.com/2015/06/how-to-protect-yourbrand-in-vietnam.html

Hassanein, K., \& Head, M. (2007). Manipulating perceived social presence through the web interface and its impact on attitude towards online shopping. International Journal of Human-Computer Studies, 65(8), 689-708. http://dx.doi.org/10.1016/j.ijhcs.2006.11.018

Heinonen, K. (2011). Consumer activity in social media: Managerial approaches to consumers' social media behavior. Journal of Consumer Behaviour, 10(6), 356-364. http://dx.doi.org/10.1002/cb.376

Hom, E.J. (2013, September 11). What is C2C? Retrieved from http://www. businessnewsdaily.com/5084-what-is-c2c.html

Hooper, B. (2000). Globalisation and resistance in post-Mao China: The case of foreign consumer products. Asian Studies Review, 24(4), 439-470. http:// dx.doi.org/10.1080/10357820008713286

Hoyle, B. (2017, December 13). YouTuber Ryan, aged 6, joins biggest-earning intenet stars with $\$ 11 m$ income. Retrieved from https://www.thetimes.co.uk/ article/youtuber-ryan-aged-6-joins-biggest-earning-intenet-stars-with-11mincome-6tjdnnbn5

Huang, J.-H., Lee, B.C.-Y., \& Ho, S.H. (2004). Consumer attitude toward gray market goods. International Marketing Review, 21(6), 598-614. http://dx.doi. org/10.1108/02651330410568033 
Hwang, H., Peng, C.-H., \& Shih, P.-C. (2014). Parallel imports, product innovation and market structures. International Review of Economics $\mathcal{E}$ Finance, 34(November), 237-245. http:/ / dx.doi.org/10.1016/j.iref.2014.08.003

Ito, M. (2016, May 15). Century-old Japan shirt brand reborn in Vietnam. Retrieved from http://asia.nikkei.com/Japan-Update/Century-old-Japan-shirt-brandreborn-in-Vietnam?page $=1$

Johnson, D.D.-P., Price, M.E., \& Van Vugt, M. (2013). Darwin's invisible hand: Market competition, evolution and the firm. Journal of Economic Behavior $\mathcal{E}$ Organization, 90(S), S128-S140. http:/ / dx.doi.org/10.1016/j.jebo.2012.12.016

Johnson, G.D., \& Grier, S.A. (2013). Understanding the influence of crosscultural Consumer-to-Consumer Interaction on consumer service satisfaction. Journal of Business Research, 66(3), 306-313. http://dx.doi.org/10. 1016/j.jbusres.2011.08.010

Jones, K., \& Leonard, L.N.-K. (2008). Trust in consumer-to-consumer electronic commerce. Information $\mathcal{E}$ Management, 45(2), 88-95. http://dx.doi.org/ 10.1016/j.im.2007.12.002

Kaplan, A.M., \& Haenlein, M. (2010). Users of the world, unite! The challenges and opportunities of Social Media. Business Horizons, 53(1), 59-68. http:/ / dx.doi.org/10.1016/j.bushor.2009.09.003

Kaynak, E., Kucukemiroglu, O., \& Hyder, A.S. (2000). Consumers' country-oforigin (COO) perceptions of imported products in a homogenous lessdeveloped country. European Journal of Marketing, 34(9/10), 1221-1241. http:/ / dx.doi.org/10.1108/03090560010342610

Khang, H., Ki, E.-J., \& Ye, L. (2012). Social media research in advertising, communication, marketing, and public relations, 1997-2010. Journalism $\mathcal{E}$ Mass Communication Quarterly, 89(2), 279-298. http://dx.doi. org/10.1177/1077699012439853

Kim, A.J., \& Johnson, K.K.-P. (2016). Power of consumers using social media: Examining the influences of brand-related user-generated content on Facebook. Computers in Human Behavior, 58(May), 98-108. http://dx.doi. org/10.1016/j.chb.2015.12.047

Kim, Y., \& Peterson, R.A. (2017). A meta-analysis of online trust relationships in e-commerce. Journal of Interactive Marketing, 38(May), 44-54. http:/ / dx.doi. org/10.1016/j.intmar.2017.01.001

Kim, Y., Sohn, D., \& Choi, S.M. (2011). Cultural difference in motivations for using social network sites: A comparative study of American and Korean college students. Computers in Human Behavior, 27(1), 365-372. http:// dx.doi.org/10.1016/j.chb.2010.08.015

Klepper, S. (1996). Entry, exit, growth, and innovation over the product life cycle. The American Economic Review, 86(3), 562-583.

Knoll, M.S. (1961). Gray-market imports: Causes, consequences and responses. Law $\mathcal{E}$ Policy in International Business, 18, 145-216.

Koo, D.-M., Kim, J.-J., \& Lee, S.-H. (2008). Personal values as underlying motives of shopping online. Asia Pacific Journal of Marketing and Logistics, 20(2), 156173. http:/ / dx.doi.org/10.1108/13555850810864533 
Kuanpoth, J. (2007). Patents and access to antiretroviral medicines in Vietnam after World Trade Organization accession. The Journal of World Intellectual Property, 10(3/4), 201-224. http://dx.doi.org/10.1111/j.17471796.2007.00321.x

Kwon, O., \& Wen, Y. (2010). An empirical study of the factors affecting social network service use. Computers in Human Behavior, 26(2), 254-263. http:// dx.doi.org/10.1016/j.chb.2009.04.011

Lamberton, C., \& Stephen, A.T. (2016). A thematic exploration of digital, social media, and mobile marketing: Research evolution from 2000 to 2015 and an agenda for future inquiry. Journal of Marketing, 80(6), 146-172. http:// dx.doi.org/10.1509/jm.15.0415

Li, D., Li, J., \& Lin, Z. (2008). Online consumer-to-consumer market in China A comparative study of Taobao and eBay. Electronic Commerce Research and Applications, 7(1), 55-67. http://dx.doi.org/10.1016/j.elerap.2007.02.010

Lin, F.-T., Wu, H.-Y., \& Tran, T.N.N. (2015). Internet banking adoption in a developing country: An empirical study in Vietnam. Information Systems and e-Business Management, 13(2), 267-287. http://dx.doi.org/10.1007/ s10257-014-0268-x

Lin, K.-Y., \& Lu, H.-P. (2011). Why people use social networking sites: An empirical study integrating network externalities and motivation theory. Computers in Human Behavior, 27(3), 1152-1161. http://dx.doi.org/10.1016/ j.chb.2010.12.009

Lin, T.-C., Cheng, H.K., Wang, F.-S., \& Chang, K.-J. (2012). A study of online auction sellers' intention to switch platform: The case of Yahoo!Kimo versus Ruten eBay. Decision Sciences, 43(2), 241-272. http://dx.doi. org/10.1111/j.1540-5915.2011.00347.x

Liu, W., Chang, L.-Y., \& Lin, J.-R. (2012). Consumer lifestyle matters: Evidence from gray markets in China. Journal of Service Science and Management, 5(2), 196-205. http://dx.doi.org/10.4236/jssm.2012.52024

Malueg, D.A., \& Schwartz, M. (1994). Parallel imports, demand dispersion, and international price discrimination. Journal of International Economics, 37(3/4), 167-195. http://dx.doi.org/10.1016/0022-1996(94)90044-2

Mathur, L.K. (1995). The impact of international gray marketing on consumers and firms. Journal of Euromarketing, 4(2), 39-59. http://dx.doi.org/10.1300/ J037v04n02_04

Michaelidou, N., Siamagka, N. T., \& Christodoulides, G. (2011). Usage, barriers and measurement of social media marketing: An exploratory investigation of small and medium B2B brands. Industrial Marketing Management, 40(7), 1153-1159. http://dx.doi.org/10.1016/j.indmarman.2011.09.009

Ministry of Foreign Affairs of Viet Nam (MoFA). (2012). Review of Vietnamese migration abroad. Hanoi: Author.

Miyazaki, A.D., \& Fernandez, A. (2001). Consumer perceptions of privacy and security risks for online shopping. The Journal of Consumer Affairs, 35(1), 2744. http://dx.doi.org/10.1111/j.1745-6606.2001.tb00101.x 
Ngai, E.W.-T., Tao, S.S.-C., \& Moon, K.K.-L. (2015). Social media research: Theories, constructs, and conceptual frameworks. International Journal of Information Management, 35(1), 33-44. http://dx.doi.org/10.1016/j.ijinfomgt. 2014.09.004

Nguyen, K.G., \& Yui, M. (2016, July 25). As Japan grays, retailers covet youthful masses in Vietnam. Retrieved from https://www.bloomberg.com/news/ articles/2016-07-24/as-japan-grays-retailers-covet-youthful-masses-invietnam

Nguyen, T.M., Nguyen, A.H., \& Phung, T.X.H. (2016). The role of social media in the apparel retail sector in Vietnam: A study of Facebook fan pages. Journal of Digital \& Social Media Marketing, 4(3), 292-309.

Nielsen. (2018, June 29). Vietnam consumer confidence index of the first quarter in 2018 reached a new all-time high of 124 points. Retrieved from http://www. nielsen.com/content/dam/nielsenglobal/vn/docs/PR_EN/2018/articlevietnam-cci-q1-2018.pdf

Nikkei. (2018, April 23). Consumers power strong Vietnam growth, FTCR finds. Retrieved from https://asia.nikkei.com/Editor-s-Picks/FT-ConfidentialResearch/Consumers-power-strong-Vietnam-growth-FTCR-finds

Nippon Communications Foundation. (2016, March 29). Japan's foreign population climbs to all-time high. Retrieved from http://www.nippon.com/en/ features/h00137/

O'Keeffe, G.S., \& Clarke-Pearson, K. (2011). The impact of social media on children, adolescents, and families. Pediatrics, 127(4), 800-804. http:// dx.doi.org/10.1542/peds.2011-0054

Opoku, R.A., \& Akorli, P.A.K. (2009). The preference gap: Ghanaian consumers' attitudes toward local and imported products. African Journal of Business Management, 3(8), 350-357.

Phang, C.W., Zhang, C., \& Sutanto, J. (2013). The influence of user interaction and participation in social media on the consumption intention of niche products. Information \& Management, 50(8), 661-672. http://dx.doi.org/ 10.1016/j.im.2013.07.001

Richardson, M. (2002). An elementary proposition concerning parallel imports. Journal of International Economics, 56(1), 233-245. http://dx.doi.org/ 10.1016/S0022-1996(01)00110-6

Richardson, S.A., Dohrenwend, B.S., \& Klein, D. (1965). Interviewing - its forms and functions. New York, NY: Basic Books.

Robinson, O.C. (2014). Sampling in interview-based qualitative research: A theoretical and practical guide. Qualitative Research in Psychology, 11(1), 2541. http://dx.doi.org/10.1080/14780887.2013.801543

Rubin, H.J., \& Rubin, I.S. (1995). Qualitative interviewing - The art of hearing data. Thousand Oaks, CA: SAGE.

Santus, R. (2015, February 11). Facebook adds Craigslist-like features for buying and selling. Retrieved from http://mashable.com/2015/02/10/facebook-forsale-groups/\#ataFWcE6Yuqk 
Saumure, K., \& Given, L.M. (2008). Data saturation. In L.M. Given (ed.), The SAGE encyclopedia of qualitative research methods (pp. 195-196). Thousand Oaks, CA: SAGE.

Shen, B., \& Bissell, K. (2013). Social media, social me: A content analysis of beauty companies' use of Facebook in marketing and branding. Journal of Promotion Management, 19(5), 629-651. http:/ /dx.doi.org/10.1080/10496491. 2013.829160

Shostack, G.L. (1982). How to design a service. European Journal of Marketing, 16(1), 49-63. http:/ / dx.doi.org/10.1108/EUM0000000004799

Simba, A., Smith, D.J., \& Dube, T. (2018). Competing with the grey market: Puzey and Payne in Zimbabwe. The CASE Journal. http://dx.doi. org/10.1108/TCJ-03-2017-0027

Stage, C. (2013). The online crowd: A contradiction in terms? On the potentials of Gustave Le Bon's crowd psychology in an analysis of affective blogging. Distinktion: Scandinavian Journal of Social Theory, 14(2), 211-226. http:// dx.doi.org/10.1080/1600910X.2013.773261

Statista. (2018). Number of social network users in Vietnam from 2015 to 2022 (in millions). Retrieved from https://www.statista.com/statistics/489217/ number-of-social-network-users-in-vietnam/

Stern, B.B., Royne, M.B., Stafford, T.F., \& Bienstock, C.C. (2008). Consumer acceptance of online auctions: An extension and revision of the TAM. Psychology \& Marketing, 25(7), 619-636. http://dx.doi.org/10.1002/mar. 20228

The Levin Institute. (2015). Why do nations import? Retrieved from http:/ / www. globalization101.org/why-do-nations-import/

Tomiyama, A. (2016, February 28). Vietnamese turn Facebook into giant bazaar. Retrieved from http://asia.nikkei.com/Business/Consumers/Vietnameseturn-Facebook-into-giant-bazaar?page $=1$

Ton, H.T.-H., \& Dao, T.K. (2014). The effects of psychology on individual investors' behaviors: Evidence from the Vietnam stock exchange. Journal of Management and Sustainability, 4(3), 125-134. http:/ /dx.doi.org/10.5539/ jms.v4n3p125

Tran, Q., Zhang, C., Sun, H., \& Huang, D. (2014). Initial adoption versus institutionalization of e-procurement in construction firms: An empirical investigation in Vietnam. Journal of Global Information Technology Management, 17(2), 91-116. http://dx.doi.org/10.1080/1097198X.2014. 928565

Tuoi Tre News. (2014a, August 28). Samsung Vietnam prioritizes local part suppliers, but few qualify: general director. Retrieved from http:// tuoitrenews.vn/business/21969/samsung-vietnam-prioritizes-local-partsuppliers-but-few-qualify-general-director

Tuoi Tre News. (2014b, September 29). 20 iPhone 6s confiscated from grey market trader in Vietnam. Retrieved from http://tuoitrenews.vn/business/ 22827/20-iphone-6s-confiscated-from-grey-market-trader-in-vietnam 
Tuoi Tre News. (2017, February 20). Ho Chi Minh City official wants to tax Facebook shops. Retrieved from http://tuoitrenews.vn/business/39648/ho-chiminh-city-official-wants-to-tax-facebook-shops

Turban, E., King, D., Lee, J.K., Liang, T.-P., \& Turban, D.C. (2015). Electronic commerce - A managerial and social networks perspective (8th ed.). Dordrecht: Springer.

Valenzuela, S., Park, N., \& Kee, K.F. (2009). Is there social capital in a social network site?: Facebook use and college students' life satisfaction, trust, and participation. Journal of Computer-Mediated Communication, 14(4), 875901. http://dx.doi.org/10.1111/j.1083-6101.2009.01474.x

Viet Nam News. (2017, March 4). More than 590 firms receive Vietnamese High-Quality Goods awards. Retrieved from http://vietnamnews.vn/ economy /372238/more-than-590-firms-receive-vietnamese-high-qualitygoods-awards.html\#W8uf25IXZ7hbQEwf.97

Vietnam Investment Review. (2012, July 31). Foreign groups deepen Vietnam distribution market roots. Retrieved from http://www.vir.com.vn/foreigngroups-deepen-vietnam-distribution-market-roots.html

Vietnamnet. (2017, March 21). VN pursues dream of auto industry. Retrieved from http://english.vietnamnet.vn/fms/business/174966/vn-pursues-dream-ofauto-industry.html

Voice of Vietnam. (2016, September 05). Vietnamese prefer to patronize foreign-made goods. Retrieved from http://english.vov.vn/market/vietnamese-preferto-patronize-foreignmade-goods-319212.vov

Vural, Ö.F. (2015). Positive and negative aspects of using social networks in higher education: A focus group study. Educational Research and Reviews, 10(8), 1147-1166.

Wang, C.-L., Siu, N.Y.-M., \& Hui, A.S.-Y. (2004). Consumer decision-making styles on domestic and imported brand clothing. European Journal of Marketing, 38(1/2), 239-252. http:// dx.doi.org/10.1108/03090560410511212

Weinberg, B.D., \& Davis, L. (2005). Exploring the WOW in online-auction feedback. Journal of Business Research, 58(11), 1609-1621. http://dx.doi. org/10.1016/j.jbusres.2004.06.004

Wu, F., Li, H.-H., \& Kuo, Y.-H. (2011). Reputation evaluation for choosing a trustworthy counterparty in $\mathrm{C} 2 \mathrm{C}$ e-commerce. Electronic Commerce Research and Applications, 10(4), 428-436. http://dx.doi.org/10.1016/j.elerap.2010. 09.004

Yang, Z., \& Fang, X. (2004). Online service quality dimensions and their relationships with satisfaction: A content analysis of customer reviews of securities brokerage services. International Journal of Service Industry Management, 15(3), 302-326. http:/ / dx.doi.org/10.1108/09564230410540953

Yeh, J.-C., Hsiao, K.-L., \& Yang, W.-N. (2012). A study of purchasing behavior in Taiwan's online auction websites - Effects of uncertainty and gender differences. Internet Research, 22(1), 98-115. http://dx.doi. org/10.1108/10662241211199988 
Yen, C.-H., \& Lu, H.-P. (2008). Factors influencing online auction repurchase intention. Internet Research, 18(1), 7-25. http://dx.doi.org/10.1108/106622 40810849568

Young, R., Len-Ríos, M., \& Young, H. (2017). Romantic motivations for social media use, social comparison, and online aggression among adolescents. Computers in Human Behavior, 75(October), 385-395. http://dx.doi.org/ 10.1016/j.chb.2017.04.021

Zhang, M.W.-B., Tran, B.X., Le, T.H., Nguyen, D.H., Nguyen, H.L.T, Tran, D.T., Latkin, C., Ho, R.C.-M. (2017). Internet addiction and sleep quality among Vietnamese youths. Asian Journal of Psychiatry, 28(August), 15-20. http:// dx.doi.org/10.1016/j.ajp.2017.03.025

Zhang, T., Omran, B.A., \& Cobanoglu, C. (2017). Generation Y's positive and negative eWOM: Use of social media and mobile technology. International Journal of Contemporary Hospitality Management, 29(2), 732-761. http://dx. doi.org/10.1108/IJCHM-10-2015-0611

Zhou, L., \& Hui, M.K. (2003). Symbolic value of foreign products in the People's Republic of China. Journal of International Marketing, 11(2), 36-58. http:// dx.doi.org/10.1509/jimk.11.2.36.20163 


\section{Appendix}

\section{Examples of Interview Questions}

\begin{tabular}{|c|c|c|c|}
\hline $\begin{array}{l}\text { Research } \\
\text { Question }\end{array}$ & $\begin{array}{l}\text { Social Media } \\
\text { Use }\end{array}$ & $\mathrm{C} 2 \mathrm{C}$ & $\begin{array}{l}\text { Parallel Imported } \\
\text { Products }\end{array}$ \\
\hline RQ1. Why? & $\begin{array}{l}\text { What do you } \\
\text { usually do on } \\
\text { FB? }\end{array}$ & $\begin{array}{l}\text { What do you usually } \\
\text { buy on FB pages? } \\
\text { From which FB pages } \\
\text { do you usually buy } \\
\text { these products? } \\
\text { Why do you choose } \\
\text { these FB pages? }\end{array}$ & $\begin{array}{l}\text { Which parallel products do } \\
\text { you usually buy? How much } \\
\text { do you know about parallel } \\
\text { products? (For example, } \\
\text { their origins, how they were } \\
\text { brought into the other } \\
\text { country, how they were } \\
\text { imported to Vietnam, } \\
\text { customs procedure?) }\end{array}$ \\
\hline RQ2. How? & $\begin{array}{l}\text { What are the } \\
\text { benefits of } \\
\text { using FB? } \\
\text { What do you } \\
\text { do to take } \\
\text { advantage of } \\
\text { these benefits? }\end{array}$ & $\begin{array}{l}\text { What are the benefits } \\
\text { of buying on FB? } \\
\text { What do you do to } \\
\text { take advantage of } \\
\text { these benefits? }\end{array}$ & $\begin{array}{l}\text { What are the benefits of } \\
\text { buying and using parallel } \\
\text { products? What do you do } \\
\text { to take advantage of these } \\
\text { benefits? }\end{array}$ \\
\hline RQ2. How? & $\begin{array}{l}\text { What are your } \\
\text { concerns when } \\
\text { using FB? } \\
\text { What do you } \\
\text { do to eliminate } \\
\text { your concerns? }\end{array}$ & $\begin{array}{l}\text { What are your } \\
\text { concerns when } \\
\text { buying on FB? What } \\
\text { do you do to } \\
\text { eliminate your } \\
\text { concerns? }\end{array}$ & $\begin{array}{l}\text { What are your concerns } \\
\text { when buying and using } \\
\text { parallel products? What do } \\
\text { you do to eliminate your } \\
\text { concerns? }\end{array}$ \\
\hline
\end{tabular}


